\title{
Clostridium thermoalcaliphilum sp. nov., an Anaerobic and Thermotolerant Facultative Alkaliphile
}

\author{
YOUHONG LI,${ }^{1}$ MARCELLA ENGLE,${ }^{1}$ NORBERT WEISS,${ }^{2}$ LINDA MANDELCO,${ }^{3}$ \\ AND JUERGEN WIEGEL ${ }^{1 *}$
}

\begin{abstract}
Department of Microbiology and Center for Biological Resource Recovery, University of Georgia, Athens, Georgia 30602'; German Collection of Microorganisms and Cell Cultures, 3300 Braunschweig, Germany ${ }^{2}$; and Department of Microbiology, University of Illinois at Urbana-Champaign, Urbana, Illinois $61801^{3}$
\end{abstract}

\begin{abstract}
An anaerobic and thermophilic alkaliphile, strain $\mathrm{JW} / \mathrm{YL23-2} \mathbf{2}^{\mathrm{T}}(\mathrm{T}=$ type strain), was isolated from sewage sludge obtained from a sewage plant in Atlanta, Ga. At pH 10.1 and $50^{\circ} \mathrm{C}$, the doubling time of this strain was 19 min. Strain JW/YL23-2T, a motile rod-shaped bacterium with 2 to 12 peritrichous flagella, exhibited a negative Gram stain reaction but was gram-type positive as judged by the polymyxin B test. No heat-stable $\left(85^{\circ} \mathrm{C}, 15 \mathrm{~min}\right)$ endospores were detected. At $50^{\circ} \mathrm{C}$, growth occurred at $\mathrm{pH}$ values ranging from 7.0 to 11.0 ; the optimum pH was 9.6 to 10.1 . The temperature range for growth ranged from 27 to $57.5^{\circ} \mathrm{C}$; the optimum temperature was 48 to $51^{\circ} \mathrm{C}$ (pH 10.1). Dissimilatory sulfate reduction was not detected. The organism utilized glucose, fructose, sucrose, maltose, cellobiose, and Casamino Acids. The DNA G+C content was 32 mol\% (as determined by chemical analysis). A 16S rRNA sequence analysis revealed a $2 \%$ inferred evolutionary distance to Clostridium paradoxum. However, the cell wall type of strain JW/YL23-2 ${ }^{\mathrm{T}}$ was A4ß (L-Orn-D-Asp), while that of $C$. paradoxum was A1 $\tau$ ( $m$-diaminopimelic acid direct). On the basis of the alkaline pH values and high temperatures for optimal growth, the inability to form spores, and other characteristics different from $C$. paradoxum characteristics, strain JW/YL-23-2 was placed in a new species, Clostridium thermoalcaliphilum; JW/YL23-2 (= DSM 7309) is the type strain of this new species.
\end{abstract}

Most of the alkaliphiles that have been isolated previously are aerobic procaryotes (8), and most of the current knowledge concerning alkaliphiles has been derived mainly from studies performed with aerobic bacteria (8-10, 13). Krulwich and Guffanti (13) defined alkaliphiles as organisms that have an optimum pH for growth of 10.0 or above. Souza et al. (24) isolated a eu(bacterial), alkaliphilic, mesophilic, obligate anaerobe that presumably was a Clostridium species. This organism, however, was not well characterized, its description was not validly published, and the organism was not available for comparison. Recently, we described the isolation of a thermophilic, (eu)bacterial, obligately anaerobic alkaliphile, Clostridium paradoxum (15). Other than these (eu)bacterial strains, the only anaerobes growing at alkaline $\mathrm{pHs}$ that have been isolated previously are alkalitolerant to moderately alkaliphilic archaea (i.e., methanogens $[4,5,16$, $18,34]$ and halophiles [23]).

In this paper, we describe the characterization of a second novel thermotolerant obligately anaerobic alkaliphile isolated from the Atlanta Municipal Sewage Plant (Atlanta, $\mathrm{Ga}$.), from which $C$. paradoxum $\mathrm{L}-15-1$ was isolated previously (15). On the basis of characteristics different from the characteristics of $C$. paradoxum and other thermophiles (30), we propose that this strain should be placed in a new species, Clostridium thermoalcaliphilum, until the genus Clostridium has been redefined.

\section{MATERIALS AND METHODS}

Sample collection. Samples were collected from the anaerobic digester and aerobic oxidation basin of the Atlanta Municipal Sewage Plant in serum bottles which had been flushed previously with $\mathrm{O}_{2}$-free $\mathrm{N}_{2}$ gas; each serum bottle

\footnotetext{
* Corresponding author. Fax: (706) 542-2605. Electronic mail address: jwiegel@uga.cc.uga.edu.
}

was filled to the top with a sample. Within $3 \mathrm{~h}$ the serum bottles were brought back to a laboratory for enumeration and isolation of alkaliphilic thermophiles (15).

Isolation and culture conditions. The enrichment, isolation, and general culture methods used were basically the methods described previously (15). The initial isolation experiment was conducted at 50 and $60^{\circ} \mathrm{C}$. YTG medium containing $0.5 \%(\mathrm{wt} / \mathrm{vol})$ yeast extract, $1 \%(\mathrm{wt} / \mathrm{vol})$ tryptone, and $0.3 \%$ (wt/vol) glucose in addition to the mineral base, reducing solution (15), and vitamin solution (15) was used for most of the experiments except for the tests of the growth requirement, substrate utilization (see below), dissimilatory sulfate reduction (15), and determination of the fermentation balance. Cultures were routinely incubated at $\mathrm{pH} 10.1$ to 10.5 and $50^{\circ} \mathrm{C}$. Growth requirements were determined at $50^{\circ} \mathrm{C}$ in a medium ( $\mathrm{pH} 9.8$ ) containing $50 \mathrm{mM} \mathrm{Na}_{2} \mathrm{CO}_{3}, 1 \mathrm{mM}$ $\mathrm{KCl}, 0.1 \%$ (wt/vol) $\mathrm{NH}_{4} \mathrm{Cl}, 0.3 \%$ (wt/vol) glucose, $0,0.01$, or $0.02 \%(\mathrm{wt} / \mathrm{vol})$ yeast extract, $5 \mathrm{ml}$ of a trace element solution (15) per liter, $1 \mathrm{ml}$ of a vitamin solution (15) per liter, and 1 $\mathrm{ml}$ of a reducing solution (15) per liter. Solid media contained $2.2 \%$ (wt/vol) agar (Difco Laboratories, Detroit, Mich.).

Light and electron microscopy. The morphological studies involving light microscopy and transmission electron microscopy were performed as described previously (15) by using a model PM-10AD phase-contrast microscope (Olympus Optical Co., Ltd., Tokyo, Japan) and a model JEM-100 CXII electron microscope (JEOL, Tokyo, Japan). The cells were negatively stained with $2 \%$ uranyl acetate by using the methods of Valentine et al. (26) and Beuscher et al. (2). Samples for ultrathin sectioning were prepared as previously described $(7,12,25)$ by using uranyl acetate; lead citrate was used for poststaining. The Gram type (29) was determined by using the unequivocal lipopolysaccharide-polymyxin B assay (31).

pH and temperature ranges for growth. The temperature and $\mathrm{pH}$ ranges for growth were determined by using YT and YTG media as described previously (15). The various pH 
values were measured with a model $825-\mathrm{MP}$ pH meter (Fisher Scientific) equipped with a combination $\mathrm{pH}$ electrode (Sensor, Staton, Calif.) and a Fisher Scientific temperature probe. The temperature range for growth was determined with a modified temperature gradient incubator (Scientific Industries, Inc., Bohemia, N.Y.) by using a temperature range of 25 to $70^{\circ} \mathrm{C}$ (variation, $\pm 0.5^{\circ} \mathrm{C}$ ) and a shaking rate of 15 strokes per min.

Substrate utilization and fermentation products. Substrate utilization was determined by using a basic medium containing $0.1 \%$ (wt/vol) yeast extract, $50 \mathrm{mM} \mathrm{Na} \mathrm{CO}_{3}, 1 \mathrm{mM} \mathrm{KCl}$, $2 \mathrm{mM} \mathrm{Na}{ }_{2} \mathrm{PO}_{4}, 5 \mathrm{ml}$ of a trace element solution per liter, and $1 \mathrm{ml}$ of a reducing solution per liter, as previously described (15); this medium was supplemented with filter-sterilized prereduced test substrates (final concentration, $0.5 \% \mathrm{wt}$ / vol). Because of the longer incubation times (up to 5 days), a $\mathrm{pH}$ of 9.6 was used to minimize caramelization of the medium ingredients at the elevated temperatures used. Increases in optical density at $600 \mathrm{~nm}\left(\mathrm{OD}_{600}\right)$ of $0.1 \mathrm{U}$ or more and changes in the $\mathrm{pH}$ compared with the control containing no added substrate were considered indications of positive results for substrate utilization. The maximum incubation time used was 7 days. Cultures which exhibited marginal growth responses (changes in $\mathrm{OD}_{600}$ of around 0.05 to 1.0) were subcultured to determine whether the cultures could be adapted to grow on the substrates in question.

The test for dissimilatory sulfate reduction was performed by using Hungate tubes containing medium which consisted of $0.3 \%(\mathrm{wt} / \mathrm{vol})$ yeast extract, $0.5 \%$ (wt/vol) tryptone, $0.3 \%$ (wt/vol) glucose, $0.0025 \%$ cysteine hydrochloride, $0.1 \%$ $\mathrm{Na}_{2} \mathrm{SO}_{4}$, and $0.01 \% \mathrm{FeSO}_{4}$; the $\mathrm{pH}$ of this medium was 10.1 or 8.5 . The cultures were incubated at $50^{\circ} \mathrm{C}$ for up to 3 days, and two uninoculated tubes were used as controls.

The medium used to determine the fermentation balance contained $0.3 \%(\mathrm{wt} / \mathrm{vol})$ yeast extract, $0.5 \%$ (wt/vol) tryptone, $50 \mathrm{mM} \mathrm{Na}{ }_{2} \mathrm{CO}_{3}, 1 \mathrm{mM} \mathrm{KCl}$, a trace mineral solution, a modified Wolfe vitamin solution, and a reducing solution as described above. The cultures were incubated at $50^{\circ} \mathrm{C}$ with and without $0.3 \%$ (wt/vol) glucose at $\mathrm{pH} 10.1$ and 7.5. The contents of volatile and nonvolatile fatty acids (except acetate), alcohols, $\mathrm{H}_{2}$, and $\mathrm{CO}_{2}$ were determined by gas chromatography. Acetate and glucose contents were determined by enzymatic assays as described previously (15).

Susceptibility to antibiotics. An exponentially growing culture was inoculated $(3 \%, \mathrm{vol} / \mathrm{vol})$ into fresh media containing filter-sterilized antibiotics (each at a concentration of 50 $\mu \mathrm{g} / \mathrm{ml}$ ). The cultures were incubated at $50^{\circ} \mathrm{C}$ and $\mathrm{pH} 7.5$ or 10.1 .

Effect of $\mathrm{Na}^{+}$and $\mathrm{K}^{+}$ions on growth and motility. An exponentially growing culture was inoculated into YTG media ( $\mathrm{pH} 9.6$ or 7.5 ) containing $0.25 \%$ (wt/vol) yeast extract, $0.25 \%(\mathrm{wt} / \mathrm{vol})$ tryptone, $0.3 \%(\mathrm{wt} / \mathrm{vol})$ glucose, and various amounts of $\mathrm{NaCl}$ and $\mathrm{KCl}$. Before $\mathrm{NaCl}$ and $\mathrm{KCl}$ were added, the medium contained about $5 \mathrm{mM} \mathrm{Na}^{+}$and 4 $\mathrm{mM} \mathrm{K}{ }^{+}$.

DNA isolation and determination of $\mathbf{G}+\mathbf{C}$ content. Purified DNA was prepared from cells in the early exponential growth phase by using the method of Ausubel et al. (1), which included $\mathrm{CsCl}$ gradient ultracentrifugation. The $\mathrm{G}+\mathrm{C}$ content was determined after complete enzymatic digestion and high-performance liquid chromatography (HPLC) separation of the nucleosides as described by Whitman et al. (28) and Mesbah et al. (19).

$16 S$ rRNA sequence analysis. Total RNA was isolated from strain JW/YL23-2 $2^{\mathrm{T}}(\mathrm{T}=$ type strain) by customary procedures $(17,33)$. We used the dideoxynucleotide chain termi- nation method in which reverse transcriptase $(21,32)$ which was adapted for direct rRNA sequencing (14) was used. The synthesized strands were labeled by using $\left[\alpha-{ }^{35}\right.$ S $]$ thio-dATP (3). A standard set of primers (usually eight) specific for (eu)bacterial $16 \mathrm{~S}$ rRNAs $(14,27,32)$ was used routinely. All sequences were $>90 \%$ complete. The sequences were aligned by using a sequence editor, ae2 (C. R. Woese, University of Illinois), with a representative collection of (eu)bacterial 16S rRNAs $(20,32)$. Corrected pairwise distances (expressed as the estimated number of changes per 100 nucleotides) were computed from percentages of similarity by using the Jukes-Cantor correction (11) as modified by $\mathrm{G}$. J. Olsen (20) to accommodate the actual nucleotide ratios. Dendograms were constructed from evolutionary distance matrices by using the algorithm of De Soete (6).

Cell wall peptidoglycan analysis. Cell walls were prepared and peptidoglycan structure was determined by the methods described by Schleifer and Kandler (22). Amino acids and peptides were separated and characterized by thin-layer chromatography on cellulose sheets.

Nucleotide sequence accession number. The 16S rRNA nucleotide sequence of strain JW/YL23-2 ${ }^{\mathrm{T}}$ has been deposited in the GenBank data base under accession number L11304.

\section{RESULTS AND DISCUSSION}

Isolation. Slurries of sludge samples taken from either the aeration (oxidation) basin or the anaerobic digester of the sewage plant in Atlanta, Ga., were inoculated (5\%, vol/vol) into fresh YTG medium (pH 10.5) and incubated at $50^{\circ} \mathrm{C}$ for 3 days. The cultures usually grew to a high density $\left(\mathrm{OD}_{600}\right.$, 0.6 to $1.0 \mathrm{U}$ ) overnight (about 6 to $9 \mathrm{~h}$ ). The cultures were then serially diluted, and the two highest dilutions $\left(10^{-5}\right.$ and $10^{-6}$ ) were used to inoculate YTG agar roll tubes ( $\mathrm{pH} 10.1$ to 10.5 ), which were incubated at $50^{\circ} \mathrm{C}$ for 1 to 3 days. Colonies having diameters of 0.3 to $0.5 \mathrm{~mm}$ appeared overnight ( 9 to $12 \mathrm{~h}$ ). At least two different types of colonies were identified (C. thermoalcaliphilum-like and $C$. paradoxum-like; approximate ratio, 1:10). Single colonies were subsequently picked, immediately inoculated into fresh YTG medium, and characterized with respect to morphology and $\mathrm{pH}$ and temperature characteristics. Some colonies were white and circular and resembled $C$. paradoxum colonies (e.g., JW/YL15 colonies) (15). Cultures derived from two other colonies that had a yellow tint, isolates YL23-2 and YL24-1, were very similar. Isolate YL23-2 was chosen as the test strain used for further characterization. The purity of the strain YL23-2 culture was ensured by three additional rounds of isolation of single colonies from agar shake roll tubes in which we used different variations of media (with and without glucose; different yeast extract and peptone contents; $\mathrm{pH} 7.8$ and 10.5). The resulting culture was designated strain JW/YL23$2^{\mathrm{T}}$.

16S rRNA sequence analysis. The $16 \mathrm{~S}$ rRNA sequence of strain JW/YL $23-2^{\mathrm{T}}$ was analyzed by examining its alignment as determined by the sequence editor ae 2 with a representative collection of (eu)bacterial 16S rRNAs and by calculating the corrected pairwise (evolutionary) distances (expressed as estimated number of changes per 100 nucleotides) (Table 1). On the basis of evolutionary distances, strain JW/YL23- $2^{\mathrm{T}}$ belongs to the diverse genus Clostridium in the Clostridium-Bacillus subphylum. This strain exhibited a $2 \%$ evolutionary distance from the most closely related species, C. paradoxum (Fig. 1 and Table 1). The next most closely related species were Clostridium sordellii, Eubacterium 
TABLE 1. Evolutionary distances for C. thermoalcaliphilum and other members of the clostridial subphylum ${ }^{a}$

\begin{tabular}{|c|c|c|c|c|c|c|c|c|c|c|c|c|c|c|c|c|c|}
\hline \multirow[b]{2}{*}{ Organism } & \multicolumn{17}{|c|}{ Evolutionary distance (\%) to: } \\
\hline & 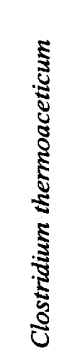 & 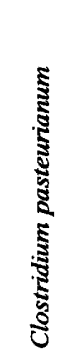 & 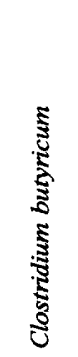 & 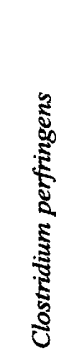 & 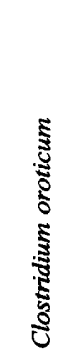 & 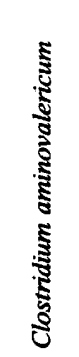 & 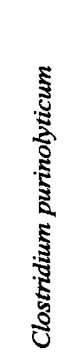 & 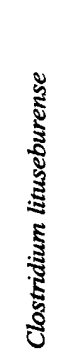 & 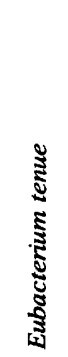 & 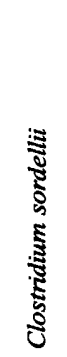 & 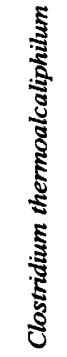 & 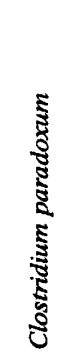 & 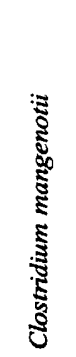 & 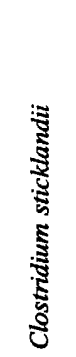 & 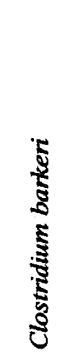 & 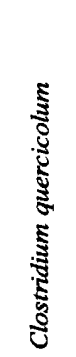 & 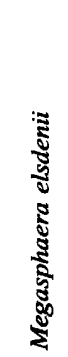 \\
\hline Clostridium pasteurianum & 17.9 & & & & & & & & & & & & & & & & \\
\hline Clostridium butyricum & 19.5 & 8.0 & & & & & & & & & & & & & & & \\
\hline Clostridium perfringens & 19.3 & 9.4 & 7.3 & & & & & & & & & & & & & & \\
\hline Clostridium oroticum & 19.7 & 18.3 & 17.5 & 16.5 & & & & & & & & & & & & & \\
\hline Clostridium aminovalericum & 19.3 & 18.0 & 17.9 & 17.3 & 8.3 & & & & & & & & & & & & \\
\hline Clostridium purinolyticum & 16.5 & 14.3 & 15.2 & 15.5 & 17.3 & 15.5 & & & & & & & & & & & \\
\hline Clostridium lituseburense & 18.6 & 18.0 & 17.1 & 15.4 & 16.6 & 15.4 & 13.5 & & & & & & & & & & \\
\hline Eubacterium tenue & 17.7 & 16.9 & 17.5 & 14.4 & 15.7 & 15.7 & 13.0 & 3.9 & & & & & & & & & \\
\hline Clostridium sordellii & 17.7 & 16.7 & 17.2 & 14.5 & 15.0 & 14.8 & 12.8 & 3.6 & 1.1 & & & & & & & & \\
\hline Clostridium thermoalcaliphilum & 16.2 & 17.3 & 17.9 & 14.5 & 16.5 & 17.2 & 13.2 & 9.6 & 7.5 & 7.8 & & & & & & & \\
\hline Clostridium paradoxum & 15.6 & 17.2 & 18.0 & 15.0 & 17.4 & 17.7 & 13.3 & 9.5 & 7.8 & 8.0 & 1.9 & & & & & & \\
\hline Clostridium mangenotii & 18.4 & 18.1 & 17.1 & 14.7 & 16.6 & 16.4 & 15.3 & 7.1 & 6.3 & 6.3 & 10.6 & 11.5 & & & & & \\
\hline Clostridium sticklandii & 18.6 & 17.5 & 18.3 & 16.0 & 18.0 & 17.3 & 15.8 & 12.5 & 10.7 & 10.8 & 10.7 & 11.2 & 13.5 & & & & \\
\hline Clostridium barkeri & 18.3 & 17.4 & 19.2 & 17.6 & 20.4 & 19.4 & 14.8 & 18.7 & 17.8 & 18.0 & 18.8 & 19.1 & 18.1 & 19.7 & & & \\
\hline Clostridium quercicolum & 16.4 & 21.1 & 22.8 & 22.8 & 22.8 & 21.7 & 18.4 & 21.1 & 21.1 & 21.1 & 21.0 & 21.2 & 20.8 & 23.0 & 21.3 & & \\
\hline Megasphaera elsdenii & 17.5 & 22.1 & 23.6 & 23.9 & 22.7 & 22.2 & 20.1 & 22.6 & 23.4 & 23.2 & 23.9 & 23.3 & 25.4 & 22.5 & 24.0 & 13.3 & \\
\hline Bacillus subtilis & 15.9 & 16.0 & 18.0 & 17.5 & 20.1 & 19.5 & 16.7 & 18.8 & 18.0 & 18.1 & 17.4 & 17.4 & 18.9 & 19.6 & 17.3 & 18.0 & 21.1 \\
\hline
\end{tabular}

${ }^{a}$ Only those positions at which bases have been determined for all sequences in the set of organisms examined were used in the analysis. Approximately 1,290 positions were used in the analysis. Bacillus subtilis was used as an outgroup.

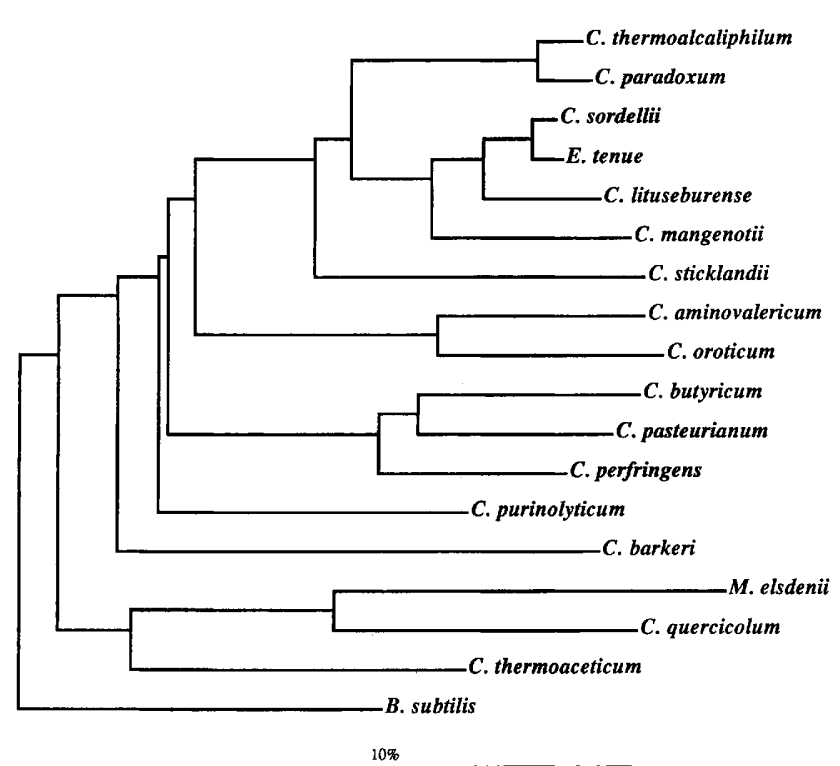

FIG. 1. Phylogenetic tree for $C$. thermoalcaliphilum and related organisms based on the results of a $16 \mathrm{~S}$ rRNA sequence analysis (see Materials and Methods). Bar $=10$ inferred changes per 100 bases. Abbreviations: C., Clostridium; E., Eubacterium; M., Megasphaera; B., Bacillus. tenue, Clostridium lithuseburense, and Clostridium mangenotii (evolutionary distances, 7.8 to $10.6 \%$ ). All of these organisms are substantially different from the type species of the genus Clostridium, Clostridium butyricum, and the species closely related to it, and which constitute the genus Clostridium sensu stricto. On the basis of distinct differences (see below) from $C$. paradoxum in 16S rRNA sequence, DNA G + C content, temperature range for growth, absence of spores, cell wall composition, and envelope structure, we concluded that strain JW/YL23-2 ${ }^{\mathrm{T}}$ is not a member of the species $C$. paradoxum or any other previously validly described species. Thus, until the genus Clostridium is redefined, strain JW/YL23-2 $2^{\mathrm{T}}$ is tentatively placed in a new species in this genus as $C$. thermoalcaliphilum.

Clostridium thermoalcaliphilum sp. nov. Clostridium thermoalcaliphilum (ther. mo. al. cal. i. phil' um. Gr. adj. thermo, hot; M.L. n. alcali, from the arabic al-qili, the ashes of the saltwort plant; M.L. adj. philum, from Gr. adj. philos, dear, loving; M.L. adj. thermoalcaliphilum, referring to the organism's optimal growth under alkaline growth conditions at elevated temperatures). The following description is based on the properties of strain JW/YL 23-2 ${ }^{\mathrm{T}}$. The morphological, $\mathrm{pH}$, and temperature characteristics of isolate YL24-1 are the same as those described below for strain JW/YL23- $2^{\mathrm{T}}$.

Colony and cell morphology. Surface colonies are circular and white with a yellowish tint. Colonies in agar are lens shaped. Cells from liquid cultures in the exponential growth phase or prepared from 1- or 2-day-old colonies are highly motile rods that are 0.8 to $1.2 \mu \mathrm{m}$ in diameter and 3 to $12 \mu \mathrm{m}$ long (Fig. 2A). Cells in early- and mid-stationary-phase cultures are significantly longer (12 to $20 \mu \mathrm{m}$ ) (Fig. 2B). Like C. paradoxum, the organism tends to develop pseudofila- 


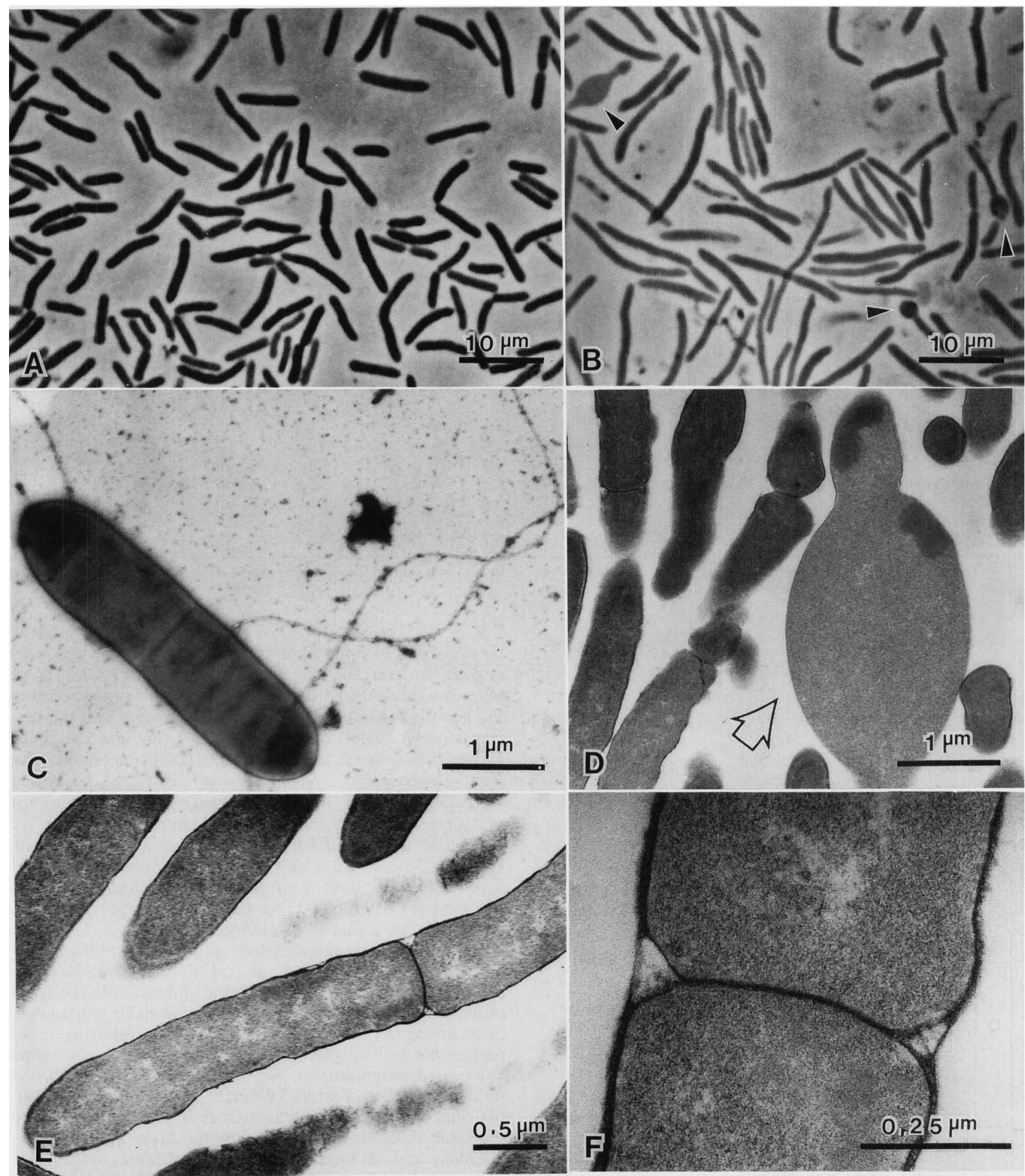

FIG. 2. Micrographs of $C$. thermoalcaliphilum. (A and B) Light micrographs. (A) Cells in the early exponential growth phase. (B) Cells in the stationary growth phase. Note the cells with swollen structures (arrowheads). (C through $F$ ) Electron micrographs. (C) Cell negatively stained with $2 \%$ uranyl acetate, showing peritrichous flagella. (D) Ultrathin section of a cell with a swollen body (arrow). (E and F) Ultrathin sections showing the fine structure of cell walls. The cultures were incubated at $\mathrm{pH} 10.1$ and $50^{\circ} \mathrm{C}$. 


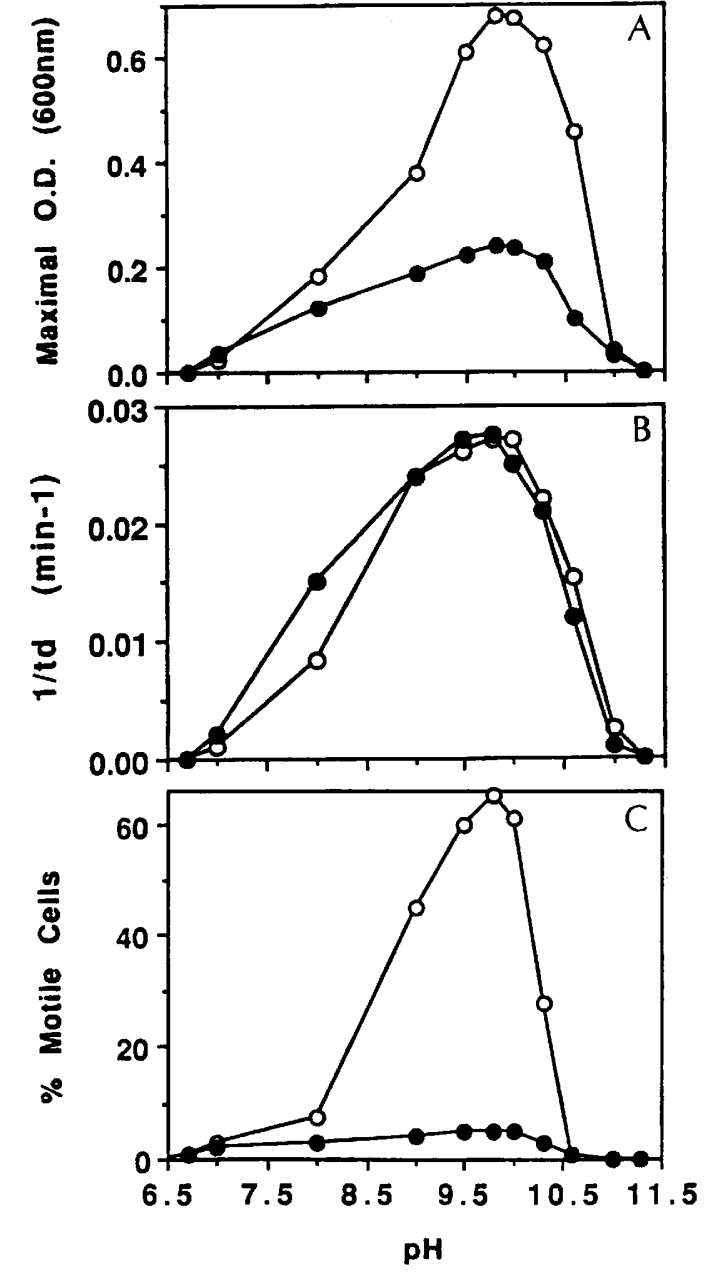

FIG. 3. (A and B) Effect of $\mathrm{pH}$ on growth as determined by maximum $\mathrm{OD}_{600}(\mathrm{~A})$ and doubling time $\left(\mathrm{t}_{\mathrm{d}}\right)(\mathrm{B})$. (C) Effect of $\mathrm{pH}$ on motility. The cultures were incubated at $48^{\circ} \mathrm{C}$ in the presence $(O)$ and in the absence $(\bullet)$ of $0.3 \%$ (wt/vol) glucose.

ments when it is grown at $\mathrm{pH}$ values of 10.9 to 11.0 (15). Swollen sporangium-like structures occur during growth at $\mathrm{pH} 10.1$ to 11.0 (Fig. 2B, arrowheads, and Fig. 2D, arrow).

Cell wall, Gram-staining reaction, and Gram type. Transmission electron micrographs of ultrathin sections (Fig. 2D through F) show that strain JW/YL23-2 $2^{\mathrm{T}}$ has a cell envelope structure different from that of $C$. paradoxum (15), especially at the cell division junction, which seems to be sheathed by an envelope structure (Fig. 2E and F). Furthermore, peptidoglycan structure analysis shows that the cell wall type of strain JW/YL23-2 ${ }^{\mathrm{T}}$ is A4 $\beta$ (L-Orn-D-Asp), while the cell wall type of $C$. paradoxum is $\mathrm{A} 1 \tau$ ( $m$-diaminopimelic acid direct). The Gram-staining reaction is negative irregardless of the growth stage; however, since no lipopolysaccharide-polymyxin B complex is detected, the organism is gram type positive $(29,31)$.

Sporulation tests. No endospores are formed after growth under various culture conditions, including after growth in agar roll tubes containing agar-solidified nutrient-deficient xylan media (at alkaline and neutral $\mathrm{pH}$ values) incubated for up to 1 week. Heat-treated cultures at all growth stages do not grow when they are incubated at 48 to $50^{\circ} \mathrm{C}$ and $\mathrm{pH} 10.0$ after the heat treatment. Cultures in the exponential or

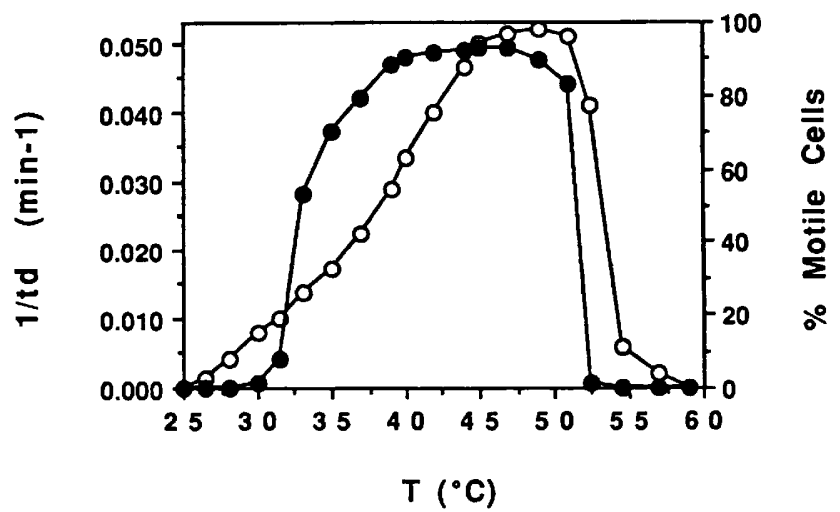

FIG. 4. Effect of temperature (T) on growth $(O)$ and motility $(O)$. The $\mathrm{pH}$ of the cultures was 10.1 . td, doubling time.

stationary growth phase left at room temperature for more than 1 week frequently cannot be subcultured, indicating that spores were not formed. The swollen structures observed (Fig. 2D), which somewhat resemble prespores in their overall shape, contain only irregular refractile substances and apparently are not heat-stable spores. As the cultures become older, these structures eventually swell further and burst. Transmission electron micrographs of ultrathin sections of the swollen structures do not indicate that $C$. thermoalcalophilum develops membrane structures that are associated with the formation of prespores (Fig. 2D) like those observed with $C$. paradoxum (15). These results indicate that this organism does not form viable spores under the conditions tested, although on the basis of the 16S rRNA sequence analysis results, it is closely related to the sporeforming organism $C$. paradoxum (see below).

Motility and flagellation. The organism is motile from the early exponential growth phase through the stationary growth phase. The cells have 2 to 12 peritrichous flagella (Fig. 2C). The flagella are 10 to $15 \mu \mathrm{m}$ long and 90 to $95 \mathrm{~nm}$ in diameter and have a wavelength of 2.5 to $3.0 \mu \mathrm{m}$.

Motility depends on the $\mathrm{pH}$ of the growth medium (Fig. 3) and the incubation temperature (Fig. 4). The organism is motile at $\mathrm{pH}$ values ranging from 7.0 to 10.6 ; the optimum $\mathrm{pH}$ for motility is around 9.8, which coincides with the optimum $\mathrm{pH}$ for growth (Fig. 3A and B). Less than $5 \%$ of the cells are motile in the absence of glucose; however, in the presence of $0.3 \%$ (wt/vol) glucose at $\mathrm{pH} 9.8$ the percentage of motile cells is $65 \%$ (Fig. 3C). When a culture that is growing exponentially at $50^{\circ} \mathrm{C}$ is used as the inoculum, motility occurs at temperatures ranging from 30 to $53^{\circ} \mathrm{C}$ (optimum temperature, 42 to $52^{\circ} \mathrm{C}$ ) (Fig. 4).

Growth properties. (i) Growth requirements. The organism is obligately anaerobic. No growth occurs when an exponentially growing culture is inoculated into aerobically prepared YTG medium, nutrient broth, or agar-solidified media. In the absence of yeast extract and tryptone, no growth occurs when an exponentially growing culture is inoculated into basic mineral media ( $\mathrm{pH} 9.8$ ) containing $0.1 \%$ (wt/vol) $\mathrm{NH}_{4} \mathrm{Cl}$ as the nitrogen source and $0.3 \%$ (wt/vol) glucose as the carbon and energy source. However, some growth $\left(\mathrm{OD}_{600}, 0.15 \mathrm{U}\right)$ does occur when $0.02 \%$ (wt/vol) yeast extract is added, indicating that yeast extract is required for growth. Tryptone but not with peptone can be used as a substitute for yeast extract.

(ii) Temperature and $\mathrm{pH}$ ranges for growth. The temperature range for growth at $\mathrm{pH} 10.1$ is 27 to $57.5^{\circ} \mathrm{C}$; the optimum 


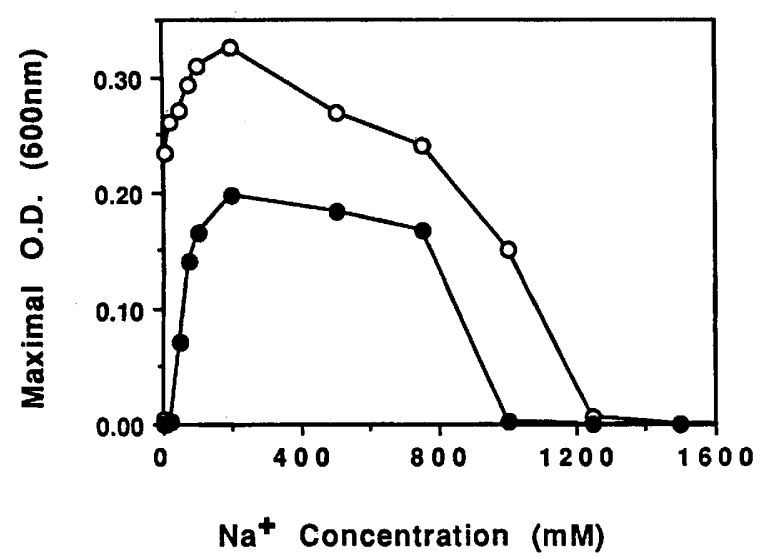

FIG. 5. Effect of $\mathrm{Na}^{+}$concentration on growth (maximum $\left.\mathrm{OD}_{600}\right)$ in the presence of $25 \mathrm{mM} \mathrm{K}^{+}(\mathrm{O})$ and $100 \mathrm{mM} \mathrm{K}^{+}(\bullet)$.

temperature for growth is between 48 and $51^{\circ} \mathrm{C}$ (Fig. 4). The $\mathrm{pH}$ range for growth is 7.0 to 11.0 at $50^{\circ} \mathrm{C}$; the optimum $\mathrm{pH}$ for growth is between 9.5 and 10.0 (Fig. 3). The same results are obtained in the presence (YTG medium) and absence (YT medium) of glucose (Fig. 3). Under optimal conditions (pH $10.1,50^{\circ} \mathrm{C}$, YTG medium), the shortest doubling time that has been observed with strain JW/YL23-2 $2^{\mathrm{T}}$ is $19 \mathrm{~min}$. This value is similar to the observed doubling time for $C$. paradoxum and relatively small compared with the reported doubling times of most other glycolytic thermophiles (30).

(iii) Effect of $\mathrm{NaCl}$ and $\mathrm{KCl}$ on growth. The $\mathrm{Na}^{+}$concentration range for growth is $5 \mathrm{mM}$ to $1.25 \mathrm{M}$ (Fig. 5). The maximum tolerated $\mathrm{Na}^{+}$concentration $(1.25 \mathrm{M})$ is much higher than the maximum tolerated $\mathrm{Na}^{+}$concentration for $C$. paradoxum (15) (about $0.75 \mathrm{M} \mathrm{NaCl}$ ). The range of $\mathrm{Na}^{+}$ concentrations at which growth occurs in the presence of 25 $\mathrm{mM} \mathrm{K}^{+}(5 \mathrm{mM}$ to $1.25 \mathrm{M})$ is a little wider than the range of $\mathrm{Na}^{+}$concentrations at which growth occurs in the presence of $100 \mathrm{mM} \mathrm{K}^{+}$(20 to $990 \mathrm{mM}$ ) (Fig. 5). A higher maximum $\mathrm{OD}_{600}$ occurs in the presence of $25 \mathrm{mM} \mathrm{K}^{+}$than in the presence of $100 \mathrm{mM} \mathrm{K}{ }^{+}$for all of the $\mathrm{Na}^{+}$concentrations that have been tested. Near the maximum tolerated $\mathrm{NaCl}$ concentration $\left(1.25 \mathrm{M}\right.$ in the presence of $25 \mathrm{mM} \mathrm{K}^{+}$and of $990 \mathrm{mM}$ in the presence of $100 \mathrm{mM} \mathrm{K}^{+}$), the morphology of the cells changes, leading to the formation of $\mathrm{L}$-form cells after $24 \mathrm{~h}$ of incubation at $50^{\circ} \mathrm{C}$. At $\mathrm{NaCl}$ concentrations higher than the maxima, the cells begin to lyze within $2 \mathrm{~h}$. At the lower $\mathrm{NaCl}$ concentrations tested (less than $5 \mathrm{mM}$ in the presence of $25 \mathrm{mM} \mathrm{K}^{+}$and less than $20 \mathrm{mM}$ in the presence of $100 \mathrm{mM} \mathrm{K}^{+}$), the cells do not grow, and the normal morphology deteriorates with prolonged incubation (after 6 $\mathrm{h}$ ), as the concentration of $\mathrm{NaCl}$ decreases.

Substrate utilization and fermentation products. In the presence of $0.1 \%(\mathrm{wt} / \mathrm{vol})$ yeast extract $(\mathrm{pH} 9.6)$, C. thermoalcaliphilum utilizes glucose, fructose, sucrose, maltose, cellobiose, and Casamino Acids. It does not utilize galactose, lactose, xylose, ribose, mannose, rhamnose, raffinose, salicin, sorbitol, mannitol, glycerol, lactate, formate, methanol, xylan, cellulose, starch, pectin, and $\mathrm{H}_{2}-\mathrm{CO}_{2}$. The fermentation products formed at $\mathrm{pH} 10.5$ and $50^{\circ} \mathrm{C}$ from the utilization of yeast extract and $2.3 \mu \mathrm{mol}$ of glucose per $\mathrm{ml}$ include $16.1 \mu \mathrm{mol}$ of acetate per $\mathrm{ml}, 3.7 \mu \mathrm{mol}$ of $\mathrm{H}_{2}$ per $\mathrm{ml}$, $1 \mu \mathrm{mol}$ of isovalerate per $\mathrm{ml}, 0.7 \mu \mathrm{mol}$ of lactate per $\mathrm{ml}$, trace amounts $(<0.5 \mu \mathrm{mol} / \mathrm{ml})$ of succinate and malate, and one unidentified product with a retention time of 14.7 to 14.8 min, but no significant amounts of bicarbonate and carbonate. Differences in product formation occur among the four conditions which we tested (Table 2). The unidentified product formed in the presence and absence of glucose has the same chromatographic properties as the product formed under similar conditions by $C$. paradoxum (15).

Biochemical properties. (i) Dissimilatory sulfate reduction. No sulfate reduction activity occurs in the presence of glucose, acetate, and lactate, thus making it unlikely that isolate $\mathrm{JW} / \mathrm{YL} 23-2^{\mathrm{T}}$ is a sulfate-reducing organism.

(ii) Fatty acid analysis. The main fatty acids are (in order of decreasing amount formed) i15:0, a15:0, i13:0, 16:0, i17:0, 14:0, and 18:0. The ester-linked phospholipid fatty acid methyl ester profile for cells grown at $\mathrm{pH} 10.0$ to 10.5 is quite similar to the profile of $C$. paradoxum grown at $\mathrm{pH} 7.5$ (15) but is distinct from the profile of $C$. paradoxum cultured at $\mathrm{pH}$ 10.5. It is interesting that $C$. paradoxum has a phospho-

TABLE 2. Fermentation product analysis for C. thermoalcaliphilum ${ }^{a}$

\begin{tabular}{|c|c|c|c|c|}
\hline \multirow[b]{2}{*}{ Substrate or product } & \multicolumn{4}{|c|}{ Amt $(\mu \mathrm{mol} / \mathrm{ml})$ used (substrate) or formed (products) ${ }^{b}$} \\
\hline & $\begin{array}{c}\text { Culture } 1 \\
\text { (pH 10.5, no glucose) }\end{array}$ & $\begin{array}{c}\text { Culture } 2 \\
(\mathrm{pH} 10.5,0.3 \% \text { glucose })\end{array}$ & $\begin{array}{c}\text { Culture } 3 \\
\text { (pH 7.5, no glucose) }\end{array}$ & $\begin{array}{c}\text { Culture } 4 \\
\text { (pH } 7.5,0.3 \% \text { glucose })\end{array}$ \\
\hline Glucose substrate & 0.05 & 2.3 & 0.02 & 1.0 \\
\hline \multicolumn{5}{|l|}{ Products } \\
\hline Acetate & 4.6 & 16.1 & 4.8 & 3.7 \\
\hline $\mathrm{H}_{2}$ & 0.9 & 3.7 & 1.4 & 1.0 \\
\hline $\mathrm{CO}_{2}$ & 0 & 0 & 2.4 & 1.7 \\
\hline Isovalerate & 0 & 1.0 & 1.0 & 0.8 \\
\hline Lactate & $\operatorname{Tr}$ & 0.7 & 0 & 0 \\
\hline Malate & $\mathrm{Tr}$ & $\operatorname{Tr}$ & 0 & $\mathrm{Tr}$ \\
\hline Pentanol & $\mathrm{Tr}$ & $\operatorname{Tr}$ & $\mathrm{Tr}$ & $\mathrm{Tr}$ \\
\hline Succinate & $\operatorname{Tr}$ & $\mathrm{Tr}$ & 0 & 0 \\
\hline Unidentified $^{c}$ & ++ & + & + & ++ \\
\hline
\end{tabular}

${ }^{a}$ Cultures of strain JW/YL $23-2^{\mathrm{T}}$ were grown at $50^{\circ} \mathrm{C}$ for $10 \mathrm{~h}$ in YT medium containing $0.3 \%$ yeast extract and $0.5 \%$ tryptone or YTG medium containing $0.3 \%$ yeast extract, $0.5 \%$ tryptone, and $0.3 \%$ glucose at $\mathrm{pH} 10.5$ or 7.5 . A culture in the early exponential growth phase was used as the inoculum (5\%, vol/vol). Tr, trace $(<0.5 \mu \mathrm{mol} / \mathrm{ml})$.

${ }^{b}$ After $10 \mathrm{~h}$ the final $\mathrm{pH}$ values of cultures 1 through 4 were $10.4,9.9,7.0$, and 6.8 , respectively. The biomasses of cultures 1 through 4 were $0.08,0.26,0.06$, and $0.07 \mathrm{mg}$ (dry weight) $/ \mathrm{ml}$.

$c$ A relatively large peak in the gas chromatogram with a retention time of 14.7 to $14.8 \mathrm{~min} .+$, peak area between 1,000 and 2,$000 ;++$, peak area between 9,000 and 15,000 . 
lipid fatty acid methyl ester profile similar to that of nonspore-forming strain JW/YL23-2 ${ }^{\mathrm{T}}$ at $\mathrm{pH} 7.0$ to $8.0, \mathrm{pH}$ values at which $C$. paradoxum does not form spores (15). However, at the present time no further conclusion can be drawn from this information.

(iii) API An-Ident tests. An-Ident tests (API Analytab Products, Plainview, N.Y.) result in positive responses for indole acetate, $\alpha$-glucosidase, arginine aminopeptidase, and arginine utilization. Negative responses occur in tests for $N$-acetyl-glucosaminidase, $\beta$-glucosidase, $\alpha$-fucosidase, phosphatase, $\alpha$-galactosidase, $\beta$-galactosidase, leucine aminopeptidase, proline aminopeptidase, pyroglutamic acid arylamidase, tyrosine aminopeptidase, alanine aminopeptidase, glycine aminopeptidase, arabinosidase, indole production, and catalase. Strain JW/YL $23-2^{\mathrm{T}}$ differs from $C$. paradoxum (Table 3 ) in the results for four tests (the indole production, $\alpha$-arabinosidase, arginine aminopeptidase, and catalase tests).

(iv) Susceptibility to antibiotics. We tested the effect of antibiotics at $50^{\circ} \mathrm{C}$. At $\mathrm{pH} 7.5$ and $10.1, C$. thermoalcaliphilum is susceptible to $50 \mu \mathrm{g}$ of penicillin $\mathrm{G}$ per $\mathrm{ml}, 50$ $\mu \mathrm{g}$ of ampicillin per $\mathrm{ml}, 50 \mu \mathrm{g}$ of metroimidazole per $\mathrm{ml}, 50$ $\mu \mathrm{g}$ of gentamicin per $\mathrm{ml}$, and $50 \mu \mathrm{g}$ of rifampin per $\mathrm{ml}$. In agreement with 16S rRNA data, this suggests that this organism is a (eu)bacterial species. For a more meaningful assessment, a detailed study of the thermostability of the antibiotics used at $\mathrm{pH} 10$ and $50^{\circ} \mathrm{C}$ needs to be done.

(v) DNA G + C content. The DNA G + C content, as determined by complete digestion of DNA with P1 nuclease and alkaline phosphatase followed by HPLC analysis $(15,19$, 28 ), is $32 \mathrm{~mol} \%$.

Maintenance. Since so far no endospores have been observed and cultures stored at room temperature frequently become nonviable within 1 week, the cultures need to be preserved in liquid nitrogen or as $50 \%$ glycerol-containing culture suspensions at -18 or $-75^{\circ} \mathrm{C}$. Such cultures are viable for at least 1 year.

Type strain. Strain JW/YL23-2, which was isolated from a sewage plant in Atlanta, Ga., is the type strain of $C$. thermoalcaliphilum sp. nov. and has been deposited in the Deutsche Sammlung von Mikroorganismen as strain DSM 7309 ; its $\mathrm{G}+\mathrm{C}$ content is $32 \mathrm{~mol} \%$.

Differentiation of $C$. thermoalcaliphilum from $C$. paradoxum and other alkaliphilic obligate anaerobes. $C$. thermoalcaliphilum is a thermotolerant (temperature range for growth, 27 to $57.5^{\circ} \mathrm{C}$ ) (30) facultative alkaliphile since it grows at $\mathrm{pH}$ values below 8.0. Its $\mathrm{pH}$ range for growth is very similar to that of $C$. paradoxum (15). These two organisms have other properties in common; they are both Gram-type positive but Gram stain negative $(29,31)$, obligately anaerobic, motile by means of peritricous flagella, and sulfate reduction negative, have short doubling times under alkaline culture conditions, and produce mainly acetate and an unknown fermentation product (Tables 2 and 3). They differ from each other, however, by $2 \%$ in both DNA G+C content and evolutionary distance derived from 16S rRNA sequence analysis. They have different cell wall compositions and different cell wall morphologies (see above). So far, $C$. thermoalcaliphilum has not been observed to form viable heat-stable endospores, while $C$. paradoxum sporulates readily under most experimental conditions (15). $C$. thermoalcaliphilum is thermotolerant, while $C$. paradoxum is a thermophile with a temperature range for growth of 30 to $63^{\circ} \mathrm{C}(15)$. These organisms are the only two obligately anaerobic, alkaliphilic (by the stringent definition of Krulwich and Guffanti $[13,15])$ species that have been described

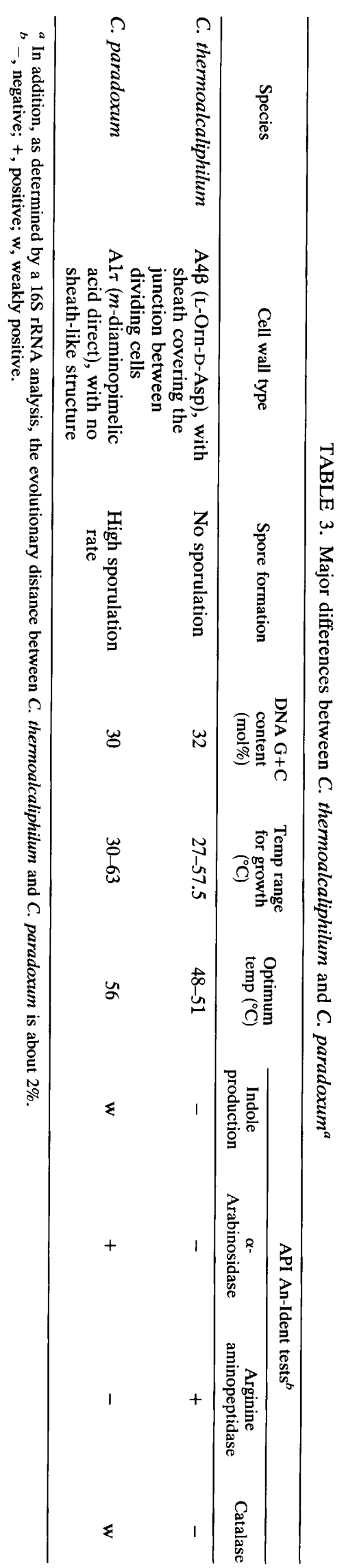


so far. Both $C$. thermoalcaliphilum and $C$. paradoxum are distinctly different from the previously described obligately anaerobic, mesophilic, spore-forming alkaliphile isolated by Souza et al. (24), which grew at $\mathrm{pH} 8.0$ to 11.3 and 27 to $30^{\circ} \mathrm{C}$. This isolate was not further characterized, and its description was not validly published; in addition, as indicated above, this organism was not available to us for comparison.

\section{ACKNOWLEDGMENTS}

We thank W. B. Whitman for help with the $\mathrm{G}+\mathrm{C}$ content determination; M. Farmer and Cathy Kelloes for help with transmission electron microscope techniques; D. C. White for the fatty acid methylester analysis; and $\mathrm{M}$. Li for help with sample collection from the Atlanta Municipal Sewage Plant, Atlanta, Ga.

This work was supported initially by an industrial grant from NOVO Nordisk, Inc., Bagsværd, Denmark, and later by grants DE-FG 09-86 ER-13614 and DE-FG 05-93 ER-20127 from the U.S. Department of Energy.

\section{REFERENCES}

1. Ausubel, F. M., et al. 1989. Current protocols in molecular biology, p. 2.4.1-2.4.5. Wiley Interscience, New York.

2. Beuscher, N., F. Mayer, and G. Gottschalk. 1974. Citrate lyase from Rhodopseudomonas gelatinosa: purification, electron microscopy and subunit structure. Arch. Microbiol. 100:307-328.

3. Biggin, M. D., T. J. Gibson, and G. F. Hing. 1983. Buffer gradient gels and ${ }^{35} \mathrm{~S}$ label as an aid to rapid DNA sequence determination. Proc. Natl. Acad. Sci. USA 80:3963-3965.

4. Blotevogel, K., U. Fischer, M. Mocha, and S. Jannsen. 1985. Methanobacterium thermoalcaliphilum spec. nov., a new moderately alkaliphilic and thermophilic autotrophic methanogen. Arch. Microbiol. 142:211-217.

5. Boone, D. R., S. Worakit, I. M. Mathrani, and R. A. Mah. 1986. Alkaliphilic methanogens from high-pH lake sediments. Syst. Appl. Microbiol. 7:230-234.

6. De Soete, G. 1983. A least square algorithm for fitting additive trees to proximity data. Psychometrika 48:621-626.

7. Frasca, J. M., and V. R. Parks. 1965. A routine technique for double-staining ultrathin sections using uranyl and lead salts. J. Cell Biol. 25:157-161.

8. Grant, W. D., and K. Horikoshi. 1988. Alkaliphiles. FEMS Symp. 49:346-366.

9. Grant, W. D., W. E. Mwatha, and B. E. Jones. 1990. Alkaliphiles: ecology, diversity and applications. FEMS Microbiol. Rev. 75:255-270.

10. Horikoshi, K. 1990. Microorganisms in alkaline environments. Kodansha, Tokyo.

11. Jukes, T. H., and C. R. Cantor. 1969. Evolution of protein molecules, p. 21-132. In H. N. Munro (ed.), Mammalian protein metabolism. Academic Press, New York.

12. Kellenberger, E., A. Ryter, and J. Sechaud. 1958. Electron microscope study of DNA-containing plasma. II. Vegetative and mature phage DNA as compared with normal bacterial nucleosides in different physiological states. J. Biophys. Biochem. Cytol. 4:671-678.

13. Krulwich, T. A., and A. A. Guffanti. 1989. Alkalophilic bacteria. Annu. Rev. Microbiol. 43:435-463.

14. Lane, D. J., B. Pace, G. J. Olsen, and D. A. Stahl. 1985. Rapid determination of $16 \mathrm{~S}$ ribosomal RNA sequences for phylogenetic analyses. Proc. Natl. Acad. Sci. USA 82:6955-6959.

15. Li, Y., L. Mandelco, and J. Wiegel. 1993. Isolation and charac- terization of a moderately thermophilic alkaliphile, Clostridium paradoxum sp. nov. Int. J. Syst. Bacteriol. 43:450-460.

16. Liu, Y., D. R. Boone, and C. Choy. 1990. Methanohalophilus oregonense sp. nov., a methylotrophic methanogen from an alkaline, saline aquifer. Int. J. Syst. Bacteriol. 40:111-116.

17. Marmur, J. 1961. A procedure for the isolation of deoxyribonucleic acid from microorganisms. J. Mol. Biol. 3:208-218.

18. Mathrani, I. M., D. R. Boone, R. A. Mah, G. E. Fox, and P. P. Lau. 1988. Methanohalophilus zhilinae sp. nov., an alkaliphilic, halophilic, methylotrophic methanogen. Int. J. Syst. Bacteriol. 38:139-142.

19. Mesbah, M., U. Premachandran, and W. B. Whitman. 1989. Precise measurement of the $\mathrm{G}+\mathrm{C}$ content of deoxyribonucleic acid by high-performance liquid chromatography. Int. J. Syst. Bacteriol. 39:159-167.

20. Olsen, G. J., R. Overbeek, N. Larsen, T. L. Marsh, M. J. McCaughey, M. A. Maciukenas, W. M. Kuan, T. J. Macke, and C. R. Woese. 1992. The ribosomal database project. Nucleic Acids Res. 20(Suppl.):2199-2200.

21. Sanger, F., S. Nicklen, and A. R. Coulson. 1977. DNA sequencing with chain-terminating inhibitors. Proc. Natl. Acad. Sci. USA 74:5463-5467.

22. Schleifer, K. H., and O. Kandler. 1972. Peptidoglycan types of bacterial cell walls and their taxonomic implications. Bacteriol. Rev. 36:407-477.

23. Shiba, H., H. Yamamoto, and K. Horikoshi. 1989. Isolation of strictly anaerobic halophiles from the aerobic surface sediments of hypersaline environments in California and Nevada. FEMS Microbiol. Lett. 57:191-196.

24. Souza, K. A., P. H. Deal, H. M. Mack, and C. E. Turnbill. 1974. Growth and reproduction of microorganisms under extremely alkaline conditions. Appl. Microbiol. 28:1066-1068.

25. Spurr, A. R. 1969. A low-viscosity epoxy resin embedding medium for electron microscopy. J. Ultrastruct. Res. 26:31-43.

26. Valentine, R. C., B. M. Shapiro, and E. R. Stadtman. 1968. Regulation of glutamine synthetase. XII. Electron microscopy of the enzyme from $E$. coli. Biochemistry 7:2143-2152.

27. Weisburg, W. G., J. G. Tully, D. L. Rose, J. P. Petzel, H. Oyaizu, D. Yang, L. Mandelco, J. Sechrest, T. G. Lawrence, J. van Etten, J. Maniloff, and C. R. Woese. 1989. A phylogenetic analysis of the mycoplasmas: basis for their classification. J. Bacteriol. 171:6455-6467.

28. Whitman, W. B., S. Sohn, D. S. Caras, and U. Premanchandran. 1986. Isolation and characterization of 22 mesophilic methanococci. Syst. Appl. Microbiol. 7:235-240.

29. Wiegel, J. 1981. Distinction between the gram reaction and the Gram type of bacteria. Int. J. Syst. Bacteriol. 31:88.

30. Wiegel, J. 1992. The obligate anaerobic thermophilic bacteria, p. 105-184. In J. K. Kristjannson (ed.), Thermophilic bacteria. CRC Press, Boca Raton, Fla.

31. Wiegel, J., and L. Quandt. 1982. Determination of the Gram type using the reaction between polymyxim B and lipopolysaccharides of the outer cell wall of whole bacteria. J. Gen. Microbiol. 128:2261-2270.

32. Woese, C. R., R. Gutell, R. Gupta, and H. F. Noller. 1983. Detailed analysis of the higher-order structure of $16 \mathrm{~S}$-like ribosomal ribonucleic acids. Microbiol. Rev. 47:621-669.

33. Woese, C. R., M. Sogin, D. A. Stahl, B. J. Lewis, and L. Bonen. 1976. A comparison of the 16S ribosomal RNAs from mesophilic and thermophilic bacilli. J. Mol. Evol. 7:197-213.

34. Worakit, S., D. R. Boone, R. A. Mah, M. Abdel-Samie, and M. M. El-Halwagi. 1986. Methanobacterium alcaliphilum sp. nov., an $\mathrm{H}_{2}$-utilizing methanogen that grows at high $\mathrm{pH}$ values. Int. J. Syst. Bacteriol. 36:380-382. 